\title{
Current Status of Botanical Pesticides for Crop Protection
}

\author{
Quang Le Dang, Chi Hwan Lim ${ }^{1}$ and Jin-Cheol Kim* \\ Eco-friendly Research Group, Division of Convergence Chemistry, Korea Research Institute of Chemical Technology, \\ Daejeon 305-600, Korea \\ ${ }^{1}$ College of Agriculture and Life Science, Chungnam National University, Daejeon 305-764, Korea
}

(Received on June 11, 2012; Revised on July 16, 2012; Accepted on September 3, 2012)

\begin{abstract}
The problems caused by synthetic pesticides have led the need for effective biodegradable pesticides with greater selectivity. Botanical pesticides are generally recognized as safe in agriculture systems. Thus, they have been regarded as attractive alternatives to synthetic chemical pesticides for the pest management. Both lower efficacy and higher costs of production make botanicals more expensive to use than conventional pesticides. Moreover, only a small portion of plant-derived metabolites among a number of bioactive metabolites are in use because commercialization of botanicals is inhibited by several problems such as toxicity, or high production cost. However, with the growing acceptance of botanical pesticides as an efficient crop protection alternative resulting in increasing demand, plant-based pesticides will play a significant role in achieving sustainable agriculture in future.
\end{abstract}

Keywords : Botanical pesticides, Plant-derived metabolites, Sustainable agriculture, Synthetic pesticides

\section{Introduction}

The agents that cause disease in plants are known to include pathogenic microorganisms such as viruses, bacteria, fungi, protozoa and nematodes. Plants also suffer from competition with weeds and are often damaged by attacks of insects. It is conservatively estimated that diseases, insects and weeds together annually interfere with the production of, or destroy, between 31 and $42 \%$ of all crops produced worldwide. Out of $36.5 \%$ average of total losses, $14 \%$ are caused by diseases, $10.2 \%$ by insects, and $12.2 \%$ by weeds. Oerke and Dehne (2004) reported that the actual losses were estimated at $26-30 \%$ for sugar beet, barley, soybean, wheat and cotton, and $35 \%, 39 \%$ and $40 \%$ for maize, potatoes and rice, respectively, for the period 1996-1998. The total annual worldwide crop loss from plant diseases is about $\$ 220$ billion (2002 prices) (Agrios, 2005).

After World War II, the agrochemical industry with discoveries of the major classes of synthetic pesticides (organochlorines, organophosphates and carbamates) provided agriculture with a vast array of crop protection chemicals such as fungicides, insecticides, nematicides,

*Corresponding author

Phone) +82-42-860-7436, Fax) +82-42-861-4913

Email)kjinc@krict.re.kr and herbicides (Jespers and De Waard, 1993). Crop growers have mainly used such synthetic agrochemicals to control plant diseases. However, overuse of these synthetic pesticides has led to resistance in plant pathogens and other numerous problems unforeseen at the time of introduction such as acute and chronic pollution, negative effects on wildlife (fish, birds), disruption of biological control and pollination, and groundwater contamination. Governments responded to these problems with regulatory action, banning or restricting the most damaging products and creating policies to make more stringent pesticide registration procedures and replace such chemicals and to pose fewer or lesser risk to human health and the environment (Gonzalez-Coloma et al., 2010; Isman, 2006).

New pesticides including botanical pesticides are being discovered and developed to replace the active compounds that are lost due to the new registration requirements. Botanical products have long been considered as crop protectants. A lot of plant derivedcompounds with pesticidal activities such as essential oil, terpenoids, lipids, sterols, alkaloids, flavanones and polyketides have been discovered and registered as biopesticides (Copping and Duke, 2007; Copping and Menn, 2000). Phytochemicals have been interested in controlling plant diseases because they are specific to target species, have often unique modes of action and little toxicity to human and are rapidly degraded into non-toxic substances under environmental conditions. 
Some of them possess modes of action different from introduced chemicals and are, therefore, lack crossresistance (Vidhyasekaran, 2004). Thus, botanical pesticides have been long recommended as attractive alternatives to synthetic chemical insecticides for pest management. The number of scientific literature documenting pesticidal activity of plant metabolites continues to increase, yet only a minority of botanical pesticides are currently used in agriculture over the world. In this paper, we reviewed plant-derived metabolites showing potent fungicidal, insecticidal, and nematicidal activities.

\section{Botanical fungicides}

Numerous phytochemicals have the potentials to control fungal diseases of crops (Copping and Duke, 2007; Engelmeier and Hadacek, 2006; Isman, 2000b). Jojoba (Simmondsia californica) oil, rosemary (Rosemarinus officianalis) oil, thyme (Thymus vulgaris) oil, clarified hydrophobic extract of neem (Azadirachta indica) oil, and cottonseed (Gossypium hirsutum) oil with garlic (Allium sativum) extract are several botanical extracts and essential oils marketed as botanical fungicides for organic farmers (Dayan et al., 2009).

Cinnamaldehyde (Fig. 1) is used in mushrooms, row crops, horticultural crops, turf and pine forests to control diseases such as dry bubble (Verticillium fungicola), and pitch canker disease (Fusarium moniliforme var subglutinans) (Copping and Duke, 2007). Its mode of action is apparently through inhibition of synthesis of the fungal cell wall component chitin (Bang et al., 2000). Thymol and carvacrol (Fig. 1) from essential oil of Thymbra spicata show strong antifungal activity against F. moniliforme, Rhizoctonia solani, Sclerotinia sclerotiorum. They efficiently inhibited all of the fungi with concentrations ranging from 50-100 $\mathrm{g} / \mathrm{ml}$ (MullerRiebau et al., 1995). $\beta$-Thujaplicin and $\gamma$-thujaplicin (Fig. 1) are monoterpenes from Calocedrus macrolepis var. formosana heartwood, exhibiting a broad antifungal spectrum against white rot fungi and brown rot fungi (Yen et al., 2008). The MIC values of $\beta$-thujaplicin and $\gamma$-thujaplicin were in the range of $5.0-50 \mu \mathrm{g} / \mathrm{ml}$. $\beta$ Caryophyllene oxide and $\alpha$-terpineol (Fig. 1) of Hypericum hyssopifolium and $H$. heterophyllum were strongly inhibitory to the growth of Fusarium species and $R$. solani at $1,000 \mu \mathrm{g} / \mathrm{ml}$ (Cakir et al., 2004). T-muurolol and $\alpha$-cadinol (Fig. 1 ) exhibited activity against $R$. solani and $F$. oxysporum with the highest antifungal indexes ranging from $60 \%$ to $85 \%$ (Chang et al., 2008). Asaroaldehyde and $\alpha$-asarone (Fig. 1) derived from Acorus gramineus rhizome were active against Phytophthora infestans and $R$. solani with control values of $50-100 \%$ at $1,000 \mu \mathrm{g} / \mathrm{ml}$ (Lee, 2007).

Singh et al. (2008) reported that securinine and allosecurinine (Fig. 1) isolated from Phyllanthus amarus completely inhibit spore germination of Alternaria spp., Heterosporium spp. and Curvularia spp. at $200 \mu \mathrm{g} / \mathrm{ml}$. Nor-sercurinine (Fig. 1) was fungicidal to $H$. frumentacei at $1,000 \mu \mathrm{g} / \mathrm{ml}$ (Sahni et al., 2005). Alkaloids neoveratalines A and B (MICs about $200 \mu \mathrm{g} / \mathrm{ml}$ ), veramitaline, stenophylline B, stenophylline B-3-O- $\beta$-D-glucopyranoside, veramiline-3-O- $\beta$-D-glucopyranoside, jervine, and jervine3-O- $\beta$-D-glucopyranoside (Fig. 1) isolated from rhizomes of Veratrum taliense exhibited strong antifungal activity to Phytophhotra capsici and Rhizoctonia cerealis (Zhou et al., 2003).

Emodin, physcion, and rhein (Fig. 1) isolated from Cassia tora showed fungicidal activities against Botrytis cinerea, Blumeria graminis f. sp. hordei, P. infestans, and $R$. solani with $\mathrm{IC}_{50}$ values in a range of $46-375 \mu \mathrm{g} / \mathrm{ml}$. Aloe-emodin had an apparent $\mathrm{IC}_{50}$ value of 177 and $275 \mu \mathrm{g} / \mathrm{ml}$ against $R$. solani and $B$. cinerea, respectively (Kim et al., 2004a, b). Chrysophanol, parietin (physcion), and nepodin (Fig. 1) isolated from roots of Rumex crispus showed activity against $B$. graminis f. sp. hordei and synergistic activity against fungus Sphaerotheca fuliginea. They controlled B. graminis f. sp. hordei with $\mathrm{IC}_{50}$ values of $4.7,0.48$ and $20 \mu \mathrm{g} / \mathrm{ml}$, respectively (Choi et al., 2004; Yang et al., 2007). Dehydro- $\alpha-$ lapachone (Fig. 1) from stems of Catalpa ovata completely inhibited the mycelial growth of $B$. cinerea, Colletotrichum spp., Magnaporthe oryzae and Pythium ultimum over a range of $0.4-33.3 \mu \mathrm{g} / \mathrm{ml}$ (Cho et al., 2006b). Cho et al. (2006a, c) also demonstrated an antifungal activity of curcumin, demethoxycurcumin and bisdemethoxycurcumin (Fig. 1) against red pepper anthracnose in a range of $0.4-100 \mu \mathrm{g} / \mathrm{ml}$. Curcumin was fungicidal to $P$. infestans, Puccinia recondita, and $R$. solani with $100 \%, 100 \%$, and $63 \%$ control values at a concentration of $500 \mu \mathrm{g} / \mathrm{ml}$ ( Kim et al., 2003).

Lignans erythro-austrobailignan-6, meso-dihydroguaiaretic acid and nectandrin-B (Fig. 1) from Myristica fragrans efficiently suppressed $A$. alternata, B. cinerea, Colletotrichum coccodes, Colletotrichum gloeosporioides, F. oxysporum, $R$. solani and $M$. oryzae with $\mathrm{IC}_{50}$ from 24 to $100 \mu \mathrm{g} / \mathrm{ml}$ (Cho et al., 2007). Four neolignans from Magnolia obovata such as magnolol, honokiol, 4-methoxyhonokiol and obovatol (Fig. 1) showed potent mycelial growth inhibition with $\mathrm{IC}_{50}$ from 7.1 to $95 \mu \mathrm{g} / \mathrm{ml}$ against Alternaria alternata, C. coccodes, F. oxysporum, M. oryzae, P. capsici, $P$. infestans, P. ultimum and $R$. solani (Choi et al., 2009).

Saponinoids including spirostanol saponins dioscin, prosapogenin of dioscin and gracillin (Fig. 1) isolated from Dioscorea collettii var. hypoglauca rhizomes induced 


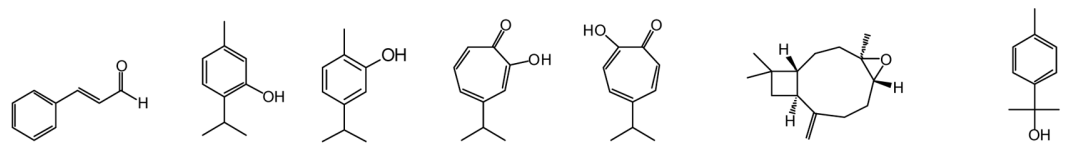

Cinnamaldehyde Thymol Carvacrol $\beta$-Thujaplicin $\gamma$-Thujaplicin $\beta$-Caryophyllene oxide $\alpha$-Terpineol
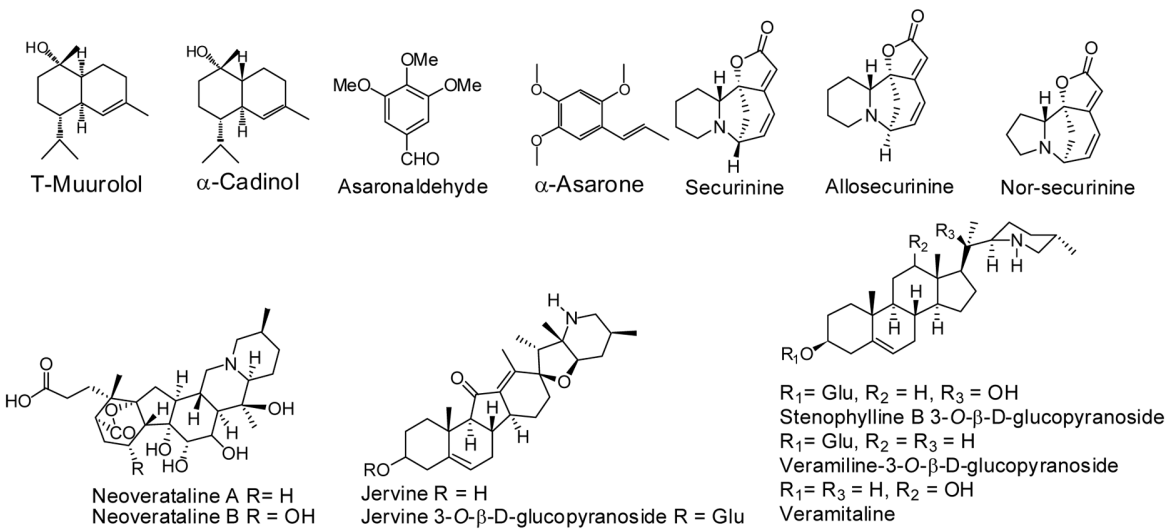<smiles>Cc1cc(O)c2c(c1)C(=O)C1C=C(O)C=C(O)C1C2=O</smiles>

Emodin<smiles>COc1cc(O)c2c(O)c3c(O)cc(C)cc3cc2c1O</smiles>

Physcion

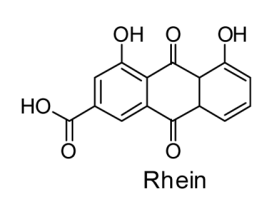

Rhein<smiles></smiles>

Aloe-emodin<smiles>Cc1cc(O)c2c(c1)C(=O)C1C=CC=C(O)C1C2=O</smiles>

Chrysophanol<smiles>CC(=O)c1c(C)cc2cccc(O)c2c1O</smiles>

Nepodin<smiles>[R]c1ccc(C[C@@H](C)[C@@H](C)Cc2ccc(O)c(OC)c2)cc1[R2]</smiles>

erythro-Austrobailignan- $6 \mathrm{R}_{1}=\mathrm{R}_{2}=\mathrm{OCH}_{2} \mathrm{O}$ meso-Dihydroguaiaretic acid $\mathrm{R}_{1}=\mathrm{OMe}, \mathrm{R}_{2}=\mathrm{OH}$

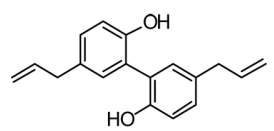

Magnolol

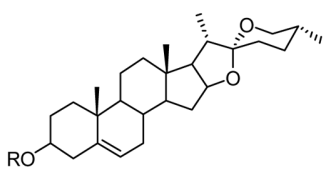

$R=-\beta-D-G I c^{2}-\alpha-L-R h a$

Prosapogenin A of dioscin

$\mathrm{R}=-\beta-\mathrm{D}-\mathrm{Glc} \underset{{ }_{4} \alpha-\text { L-Rha }}{2 \alpha-\text { L-Rha }}$

Dioscin

$R=-\beta-D-G l c \underset{3}{2} \beta-D-$ Dhlc

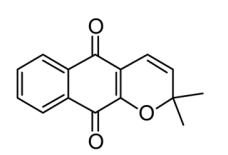

Dehydro- $\alpha$-lapachone (l)

Curcumin $\mathrm{R}_{1}=\mathrm{R}_{2}=\mathrm{OMe}$

Demethoxycurcumin $\mathrm{R}_{1}=\mathrm{H}, \mathrm{R}_{2}=\mathrm{OMe}$ Bisdemethoxylcurcumin $\mathrm{R}_{1}=\mathrm{R}_{2}=\mathrm{H}$

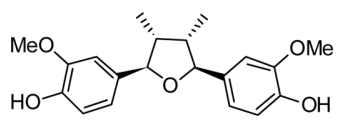

Nectandrin B

$$
\text { 4-Methoxyhonokiol } \mathrm{R}=\mathrm{CH}_{3}
$$

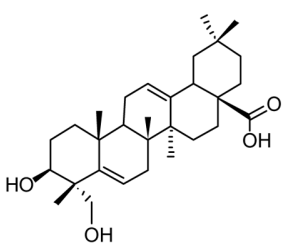

Hederagenin<smiles>C=CCc1ccc(Oc2cc(CC=C)cc(O)c2O)cc1</smiles>

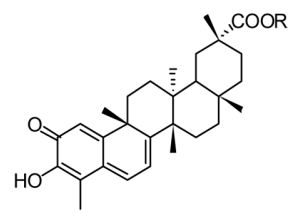

Pristimerin $\mathrm{R}=\mathrm{CH}_{3}$ Celastrol $\mathrm{R}=\mathrm{H}$

Fig. 1. Phytochemicals with antifungal activity against phytopathogenic fungi. 
morphological deformation of mycelia and conidia of $M$. oryzae with MMDC (minimum morphological deformation concentration) $2.3,5.5$ and $9.0 \mu \mathrm{M}$, respectively (Hu et al., 2003). Hederagenin aglycone (Fig. 1) was reported to be active against Rhizoctonia bataticola $\left(\mathrm{ED}_{50} 1636.0 \mu \mathrm{g} / \mathrm{ml}\right)$ and Sclerotium rolfsii $\left(\mathrm{ED}_{50} 412.5\right.$ $\mu \mathrm{g} / \mathrm{ml}$ ) (Saha et al., 2010; Saniewska et al., 2006). Quinonoid triterpenes pristimerin and celastrol (Fig. 1) from the roots of Celastrus hypoleucus, inhibited the mycelial growth of Glomerella cingulata, B. cinerea, $R$. solani and M. oryzae (Luo et al., 2005).

In the case of commercialized phytochemicals Lglutamic acid and $\gamma$-aminobutyric acid, they are introduced as active ingredients of AuxiGro used as a fungicide and plant growth regulator for fungal managements of fruits and vegetables, tree nuts, peanuts, grains, turf grasses and for preventing powdery mildew on grapes. They are not toxic to mammals or other organisms tested and they are not likely to be toxic to plants (Copping and Duke, 2007).

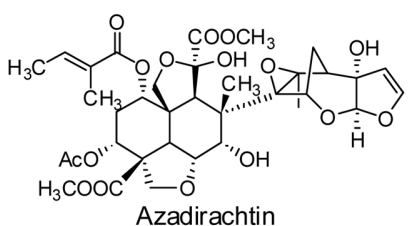

Azadirachtin

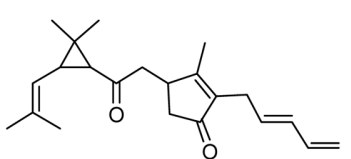

Pyrethrin I

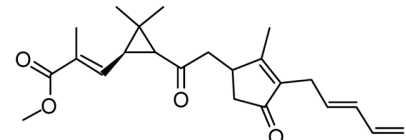

Pyrethrin II

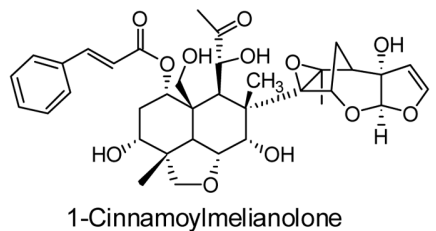
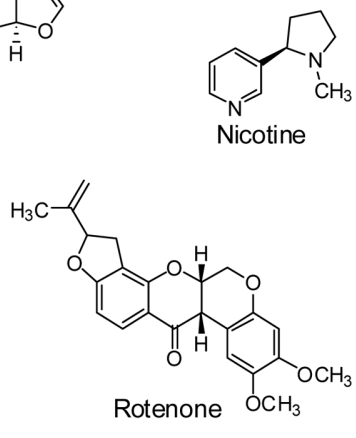<smiles>COc1c(-c2ccccc2)oc2c(ccc3occc32)c1=O</smiles><smiles>C=CC(C)(O)CCC=C(C)C</smiles><smiles>CC(O)[C@@]12CC(=O)[C@H](C)[C@H]1C2</smiles><smiles>CC1CCC(C(C)O)[C@H](O)C1</smiles>
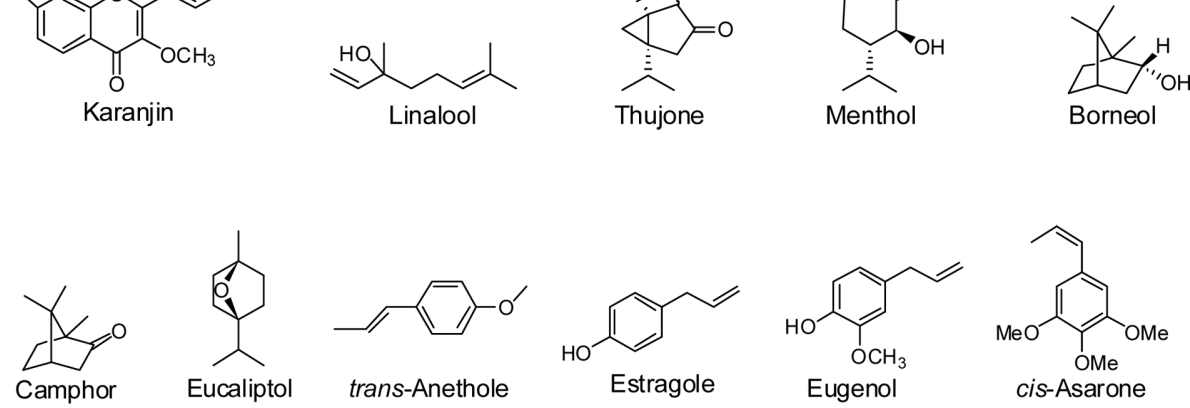<smiles>CCC(C)C1CCC(C)(O)O1</smiles><smiles>C/C=C/c1ccc(OC)cc1</smiles><smiles>C=CCc1ccc(O)cc1</smiles><smiles>C=CCc1ccc(O)c(OC)c1</smiles><smiles>C/C=C\c1cc(OC)c(OC)c(OC)c1</smiles>

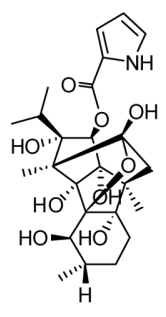<smiles>CC(C)CNC(=O)C(CC(C)C)NC(=O)/C=C/C=C/CCCC/C=C/c1ccc2c(c1)OCO2</smiles>

Ryanodine

Dihydropipericide

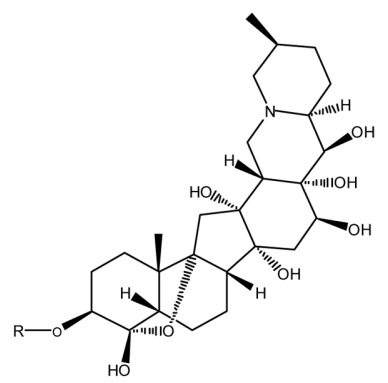

Veratridine: $\mathrm{R}=$ Veratric acid
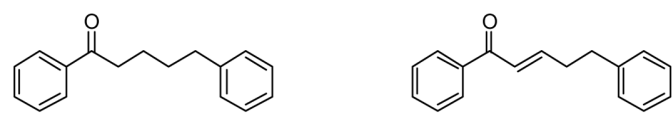

1,5-Diphenyl-2-penten-1-one

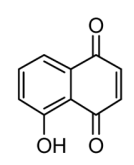

Juglone

Fig. 2. Phytochemicals with insecticidal activity against insects. 


\section{Botanical insecticides}

Botanical insecticides from phytochemical resources being used currently include azadirachtin, nicotine, pyrethrins, rotenone, and numerous essential oils. Neem seeds $(A$. indica) contain 0.2 to $0.6 \%$ azadirachtin (Fig. 2) and numerous minor azadirachtin analogs (Isman, 2006). Azadirachtin has two effects on phytophagous insects; it disrupts insect molting by blocking the synthesis and release of ecdysteroids hormones, and is a potent antifeedant to many insects (Gonzalez-Coloma et al., 2010). Azadirachtin is effective against whitefly, thrips, leaf miners, caterpillars, aphids, jassids, beetles and mealybugs (Copping and Duke, 2007). Lepidoptera were extremely sensitive to the chemical and show effective antifeedancies from below 1 to $50 \mu \mathrm{g} / \mathrm{ml}$, depending on species (Mordue and Nisbet, 2000). Azadirachtin is sold with a wide range of trade names such as Azatin, Align, Bio-neem, Bollwhip, Neem, Neemazad, Neemix, and so on (Copping and Duke, 2007).

Seeds of chinaberry tree (Melia azedarach), the most closely related genus of neem, contain a number of remarkable insecticidal triterpenoids (meliatoxins) such as 1-cinnamoylmelianolone (Fig. 2) (Isman, 2000a). The meliatoxins are abundant in chinaberry tree in Asia and toxic to mammals. However, the seeds of $M$. azadarach growing in Argentina lacked meliatoxins, but produced a notably triterpenoid meliartenin that is a strong feeding deterrent to insects (Isman, 2006).

Nicotine (Fig. 2) is the main bioactive component of the tobacco plants Nicotiana tabacum (Copping and Duke, 2007). Nicotine is a nonsystemic insecticide that binds to the cholinergic acetylcholine nicotinic receptor. Nicotin and its semi-synthetic derivatives are used for the control of a wide range of insects, including aphids, thrips and whitefly, on protected ornamentals and fieldgrown crops, including orchard fruit, vines, vegetables and ornamentals (Addor, 1995; Copping and Duke, 2007).

Pyrethrins I (Fig. 2) and II are most abundant in pyrethrum of Tanacetum cinerariaefolium and account for most of the insecticidal activity (Isman, 2006; Gonzalez-Coloma et al., 2010). Pyrethrins block voltagegate sodium channels in nerve axons, resulting in a neurotoxic action. Technical grade pyrethrum (20 to $25 \%$ pyrethrins) controls a wide range of insects and mites on fruit, vegetables, field crops, ornamentals, glasshouse crops and house plants (Copping and Duke, 2007).

Rotenone (Fig. 2) has been used for more than 150 years and is found in Derris, Lonchocarpus and Tephrosia species. It is used to control a wide range of arthropod pests, including aphids, thrips, suckers, moths, beetles and spider mites in fruit and vegetable cultivation. Rotenone is mitochondrial poison, which blocks the electron transport chain and prevents energy production. It is considered as a stomach poison because it must be ingested to be effective (Isman, 2006).

Karanjin (Fig. 2) is a furanoflavonol, a type of flavonoid. It is obtained from the seeds of the karanjin tree (Millettia pinnata $=$ Derris indica), a tree growing wild in south India. Karanjin is an acaricide and insecticide. It suppresses the effects of ecdysteroids and thereby acts as an insect growth regulator (IGR) and antifeedant. It also inhibits cytochrome P-450 in susceptible insects and mites (Gonzalez-Coloma et al., 2010).

Plant essential oils disrupt the endocrinologic balance of insects. They may be neurotoxic or may act as insect growth regulators, disrupting the normal process of morphogenesis. Several volatile substances of essential oils such as linalool (Fig. 2) have been shown as inhibitors of acetylcholinesterase (AChE) against different insect species. Thujone, thymol, menthol and borneol (Fig. 2) have been classified as a neurotoxic insecticide, which acts on GABA receptors (Rameshwar Singh, 2010). Camphor and eucalyptol (Fig. 2) are used for control the honeybee parasite varroa (Varroa facobson and $V$. destructor). trans-Anethole, estragole, eugenol (Fig. 2) and carvacrol showed topical activity to insects (Addor, 1995). Eugenol is effective on arthropod, armyworms, thrips, aphids and mites (Isman, 2000b). Cinnamaldehyde is toxic to corn rootworm and other pest of animals (Copping and Duke, 2007; Gonzalez-Coloma et al., 2010). Two asarones, a-asarone and cis-asarone (Fig. 2), caused high mortalities for Sitophilus oryzae, Callosobruchus chinensis and Lasioderma serricorne adults (Park et al., 2003).

Ryanodine (Fig. 2) and related alkaloids are poisonous alkaloids found in the stem of Caribbean shrub Rynia speciosa. It controlls codling moth (Cydia pomonella), citrus thrips in maize, apples, pears and citrus. It has extremely high affinity to the open-form ryanodine receptor, a group of calcium channels found in skeletal and heart muscle cells. It affects muscles by binding to the calcium channels in the sarcoplasmic reticulum and cause rapidly death. The effect of the nanomolar-level binding is that ryanodine causes release of calcium from calcium stores in the sarcoplasmic reticulum leading to massive muscular contractions (Copping and Duke, 2007; Isman, 2006).

Pipericide, dihydropipericide (Fig. 2) of black pepper Piper nigrum was active to adzuki bean weevil (Callosobruchus chinensis). Pipericide and dihydropipercide 
caused $\mathrm{LD}_{50}$ values 0.56 and $0.23 \mu \mathrm{g}$ /insect, respectively (Isman, 2006).

Sabadilla is a botanical insecticide from the seeds of the South American lily (Schoenocaulon officinate). The plant contains a $(2: 1)$ mixture of cevadine and veratridine (Fig. 2), which account for the insecticidal activity of the plant (Isman, 2006). They act on the voltage-sensitive sodium channels of nerve, heart, and skeletal muscle cell membranes (Gonzalez-Coloma et al., 2010). The compounds were effective against thrips (Frankliniella spp. and Thrips spp.) in citrus and avocados (Copping and Duke, 2007).

Another aphidcide, 1,5-diphenyl-2-penten-1-one and 1,5-diphenyl-1-pentanone (Fig. 2) isolated from the roots of Stellara chamaejasme caused aphicial activity against A. gossypii and Schizaphis graminum (Ping et al., 2001). ar-Turmerone (Fig. 2) caused 100 and 64\% mortality for Nilaparvata lugens female adults at 1000 and $500 \mu \mathrm{g} / \mathrm{ml}$, respectively (Lee et al., 2001). 5Hydroxy-1,4-naphthoquinone (Juglone, Fig. 2) isolated from Diospyros kaki roots was effectively active against N. lugens and Laodelphax striatellus (Jeon et al., 2011).

\section{Botanical nematicides}

Phytochemicals with nematicidal activities have been also known as botanical nematicides. Most of secondary metabolites are responsible for the nematicidal activities.<smiles>CC(=CCO)CCC=C(C)CCCC(C)=C(C)C</smiles><smiles>CC(C)=CCCC(C)=CC=O</smiles><smiles>C=CCC(C)CCC=C(C)C</smiles><smiles>C=C(C)c1ccc(C)c(O)c1</smiles><smiles>CC1=C2CC(C(C)(C)O)CCC2(C)CCC1</smiles><smiles>O=C(O)c1ccccc1O</smiles><smiles>C=CCc1ccc(OC)c(OC)c1</smiles><smiles>C/C=C/c1ccc(O)c(OCC(C)(C)C)c1</smiles><smiles>OC/C=C/c1ccccc1</smiles>
trans-Cinnamyl alcohol<smiles>CCCCCCC=CCO</smiles><smiles>CCCCCCCC=CC=O</smiles>
trans-2-Decenal

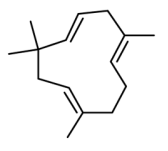

$\alpha$-Humulene

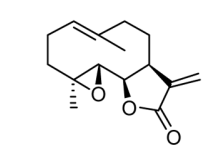

$$
\text { 4,5-Epoxy-1(10) E,11(13)- }
$$
germacradien-12,6-olide

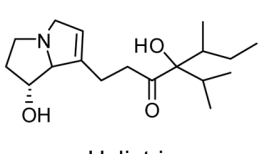<smiles>CCOC(O)(C(C)(C)C)C(C)(C)C(=O)OC</smiles>

N-Methylcytisine Monocrotaline $\mathrm{N}$-oxide

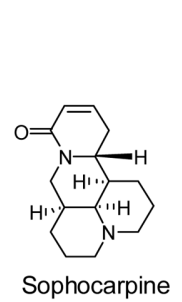

Sophocarpine<smiles>COc1cc2c3c(c1OC)CCC(NC(C)=O)C1CC(=O)C(OC)CCC3CC2C1</smiles>

Colchicine

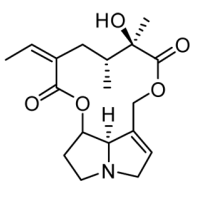

Senecionine<smiles>O=c1cccc2n1CC1CNCC2C1</smiles>

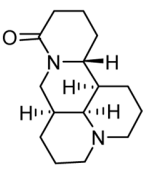

Matrine

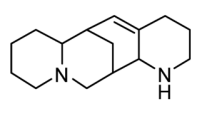

Aloperine

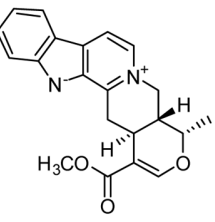

Serpentine

Fig. 3. Phytochemicals with nematicidal activity against phytoparasitic nematodes. 

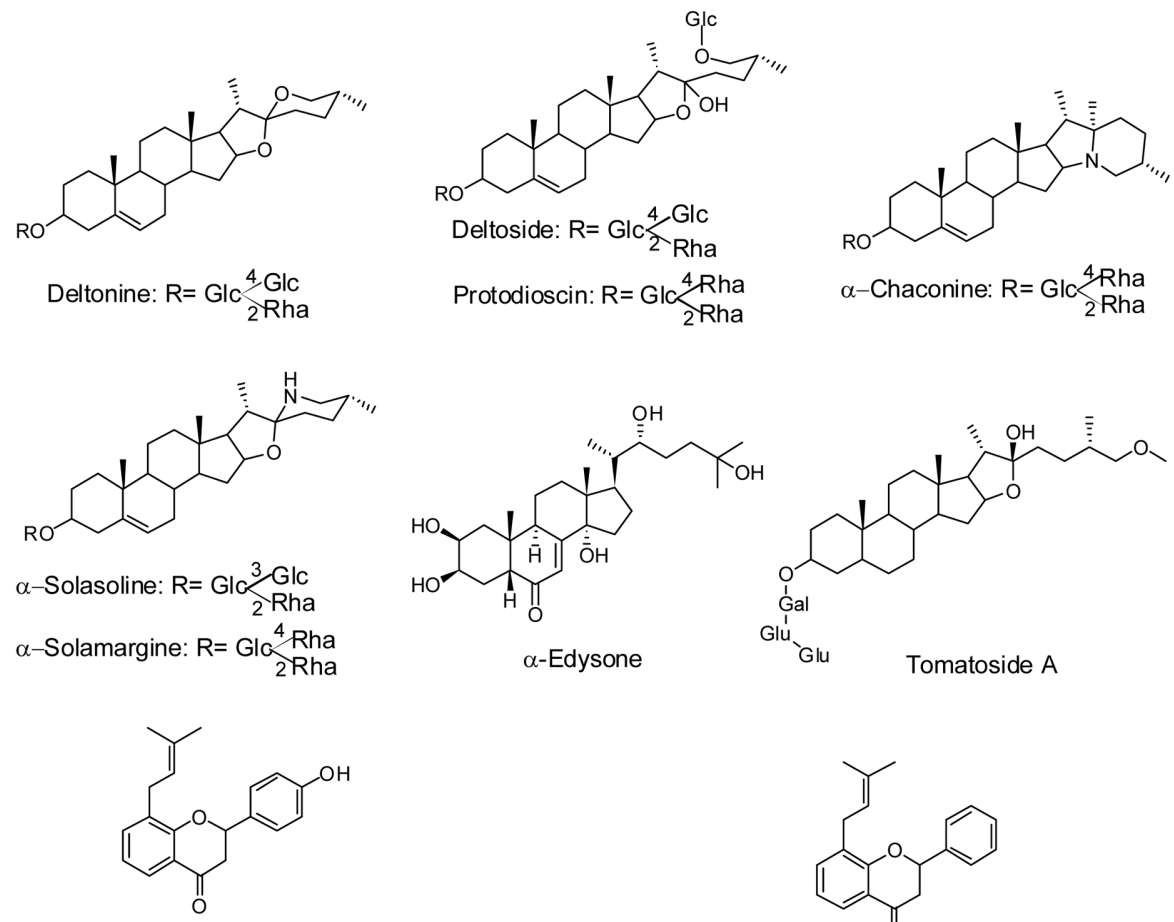

2-(4-Hydroxyphenyl)-8-(3-methyl-but-2-enyl)chroman-4-one

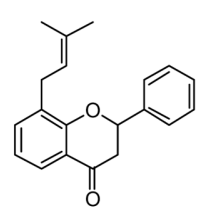

8-(3-Methyl-but-2-enyl)-2-phenyl-chroman-4-one<smiles>[R]c1ccc(CCCCCCCCCc2c(O)cccc2O)cc1O</smiles>

Malabaricone A: R1 = R2 = H

Malabaricone B: R1 = H, R2 = OH

Malabaricone $\mathrm{C}: \mathrm{R} 1=\mathrm{R} 2=\mathrm{OH}$

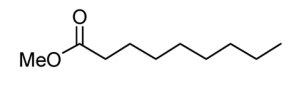

Methyl pelargonate

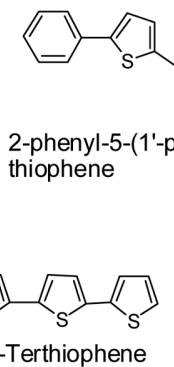

Thiarubrine $\mathrm{C}$

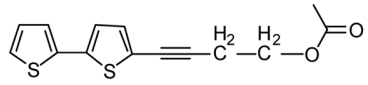

Acetoxybutinylbithiophene

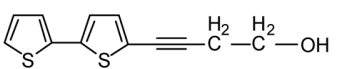

Hydroxybutinylbithiophene

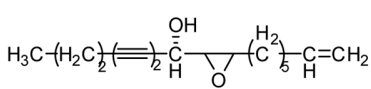

9, 10-Epoxy-heptadec-16-ene-

4, 6-diyn-8-ol

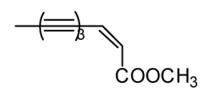

cis-Dehydromatricaria este

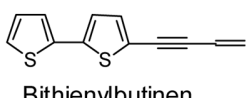

Bithienylbutinen

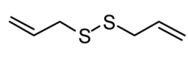

Allicin

Fig. 3. Continued.

The volatile constituents of plant essential oils are promising remarkable nematicides (Choi et al., 2007a, b; Kim et al., 2008; Kong et al., 2006, 2007a, b; Park et al., 2007). Monoterpenes presented in Fig. 3 such as citronellol (Fig. 3), geraniol, menthol, thymol, citral and cintronellal (Fig. 3) have shown noteworthy nematicidal activity against J2s pine wood nematode (PWN; Bursaphelechus xylophilus) (Choi et al., 2007a; Kim et al., 2008; Park et al., 2007). Borneol, carveol (Fig. 3), citral, geraniol and $\alpha$-terpineol are potential nematicides 
against root knot nematode (RKN); the effects of soil treatment on galling of tomato caused by Meloidogyne incognita are significant (Echeverrigaray et al., 2010; Oka et al., 2000). The $\mathrm{EC}_{50}$ values at $96 \mathrm{~h}$ after treatment against $M$. incognita of benzaldehyde, $\gamma$ eudesmol (Fig. 3) and estragole are 9, 50 and $180 \mu \mathrm{g} /$ $\mathrm{ml}$, respectively. The synergistic nematicidal interactions of terpene pairs trans-anethole/geraniol, trans-anethole/ eugenol, carvacrol/eugenol and geraniol/carvacrol were the most potent (Ntalli et al., 2011).

Salicylic acid (Fig. 3) and cinnamaldehyde were effective against RKN and provided control of galling on tomato plants (Chitwood, 2002). Eugenol $\left(\mathrm{LD}_{50}\right.$ $0.48 \mu \mathrm{g} / \mathrm{ml}$ ), methyl eugenol ( $\left.\mathrm{LD}_{50} 0.517 \mu \mathrm{g} / \mathrm{ml}\right)$, isoeugenol ( $\left.\mathrm{LD}_{50} 0.2 \mu \mathrm{g} / \mathrm{ml}\right)$ and methyl isoeugenol $\left(\mathrm{LD}_{50} 0.21 \mu \mathrm{g} / \mathrm{ml}\right)$ affected on PWN (Park et al., 2007). cis-Asarone, trans-cinnamyl alcohol, trans-2-decen-1ol, trans-2-decenal (Fig. 3), decanol, undecanal and benzaldehyde caused mortalities (77-100\%) for PWN (Kim et al., 2008).

Sesquiterpenes $\alpha$-humulene (Fig. 3) (Suga et al., 1993) from barks of Pinus species and 4,5-epoxy-1(10) E,11(13)germacradien-12,6-olide from Magnolia grandiflora (Hong et al., 2007) were active against PWN. Thoden et al. $(2009 \mathrm{a}, \mathrm{b})$ reported nematicidal activity of pyrrolizidine alkaloids heliotrine, lasiocarpine, senecionine, monocrotaline and monocrotaline $\mathrm{N}$-oxide (Fig. 3) against RKNs $M$. hapla and M. incognita. Quinolizidine alkaloids from Sophora flavescens and S. alopecuroides including Nmethylcytisine, cytisine (sophorine), matrine, aloperine and sophocarpine (Fig. 3) were significantly nematicidal PWN (Chitwood, 2002; Matsuda et al., 1989, 1991; Zhao, 1999). Among of those alkaloids, aloperine are the most effective alkaloid (Zhao, 1999). Colchicine (Fig. 3) isolated from Gloriosa superb seeds, at concentration of $1 \%$ and $2 \%$, showed nematotoxicity of $32 \%$ and $85 \%$ to $\mathrm{J} 2 \mathrm{~s}$ of $M$. incognita, respectively (Nidiry et al., 1993). Serpentine (Fig. 3) from Catharanthus roseus induced death and inhibited hatching of $M$. incognita (Chandravadana et al., 1993).

Saponins from top and root tissues of Medicago sativa showed $86-91 \%$ mortality against $M$. incognita (D'Addabbo et al., 2010). Furostanol glycosides and glycoalkaloids such as deltonine, deltoside, protodioscin, $\alpha$ chaconine, $\alpha$-solasonine, $\alpha$-solamargine, $\alpha$-ecdysone and tomatoside (Fig. 3) reduced moderately the number and size of root knots on tomato (Udalova et al., 2004). Two prenylated flavanones of Phyllanthus niruri have been evaluated their efficacy against $M$. incognita, and Rotylenchulus reniformis. The nematicidal activity against M. incognita of 8-(3-methyl-but-2-enyl)-2-phenyl chroman4-one $\left(\mathrm{LD}_{50} 70.9 \mu \mathrm{g} / \mathrm{ml}\right)$ and 2-(4-hydroxyphenyl)-8-(3- methyl-but-2-enyl)-chroman-4-one ( $\left.\mathrm{LD}_{50} 14.5 \mu \mathrm{g} / \mathrm{ml}\right)$ (Fig. 3) was dose-dependent (Shakil et al., 2008).

Miscellaneous compounds such as fatty acid derivatives, polyynes, dithiins, and furans are considered to possess the nematicidal activity (Ghisalberti, 2002). Three diarylnonanoids malabaricones $\mathrm{A}, \mathrm{B}$ and $\mathrm{C}$ (Fig. 3) from Myristica malabarica caused mortalities from 31$75 \%$ for PWN (Choi et al., 2008). Methyl pelargonate (Fig. 3) was active to $M$. incognita on soybean at concentrations less than $1.6 \mu \mathrm{g} / \mathrm{ml}$ (Davis et al., 1997).

Two polyynes pentayne and 9, 10-epoxy-heptadec-16ene-4, 6-diyn-8-ol (Fig. 3) from the roots of Cirsium japonicum inhibited reproduction of PWN. 1-Phenylhepta1, 3, 5-triyne and 2-phenyl-5-(1'-propynyl)-thiophene (Fig. 3) from Coreopsis lanceolata and cis-dehydromatricaria ester from Solidago altissima also inhibited the propagation of PWN at a dose of $110 \mu \mathrm{g} / \mathrm{ball}$ (Kawazu et al., 1980).

Thiarubrine C (Fig. 3) from the roots of Rudbeckia hirta was toxic to M. incognita and Pratylenchus penetrans at $\mathrm{LC}_{50}$ of $12.4 \mu \mathrm{g} / \mathrm{ml}$ and $23.5 \mu \mathrm{g} / \mathrm{ml}$, respectively. Thiarubrine $\mathrm{C}$ was also effective in reducing plant infection when mixed with soil 24 hours prior to or at planting, unlike other related compounds such as äterthienyl (Sánchez Deviala et al., 1998).

Marigold (Tagetes spp.) was reported to contain nematicidal principles such as $\alpha$-terthiophene, bithienylbutinen, acetoxybutinylbithiophene and hydroxybutinylbithiophene (Fig. 3) (Chitwood, 2002; Ploegn, 1999). Allicin (Fig. 3) from garlic Allium sativum caused inhibition on hatching of $M$. incognita at concentrations less than $0.5 \mu \mathrm{g} / \mathrm{ml}$ (Gupta and Sharma, 1993).

\section{Conclusions}

Sustainable agricultural development is consistently considered for most of countries to sustain the growing population. Currently, integrated crop management is playing an important role in organic farming. Biopesticides are key components of integrated crop disease management. Moreover, interest in phytochemical based-pesticides for crop protection is increasing because in public perception they are regarded as environmentally safe and less toxic to humans than synthetic chemicals. Additionally, it has been suggested that botanical extracts are more complex in comparison to synthetic pesticides and therefore, they may delay the development of resistance of phytopathogens.

Many natural product based-pesticides have been discovered up to now. Nevertheless, only about 30 different biopesticides are registered and currently marketed (Copping and Duke, 2007; Copping and 
Menn, 2000). This is mainly due to high cost, low activity, or phytotoxic effects to crops. These factors have hindered commercialization of botanical pesticides. Despite this situation, however, efforts related to botanical pesticides have increased to develop commercial products that would abate the negative effects of inappropriate and intensive use of synthetic agrochemicals. With the growing acceptance of botanical pesticides as next generation of pest control products, the major companies as well as small companies will include botanical pesticides in their portfolio. Botanical pesticides can play an important role in the production of organic food and postharvest disease protection of food as well as in achieving sustainable agriculture.

\section{Acknowledgement}

This study was carried out with the support of Cooperative Research Program for Agricultural Science \& Technology Development (Project No.: 200901OFT102966197), Rural Development Administration, Republic of Korea.

\section{References}

Addor, R. W. 1995. Insecticides. In: Agrochemicals from natural products, ed. by Godfrey, C.R.A., pp. 1-63, Marcel Dekker, New York, USA.

Agrios, G. N. 2005. Plant Pathology. 5th ed. Elsevier Academic Press, Burlington, Mass., USA.

Bang, K. H., Lee, D. W., Park, H. M. and Rhee, Y. H. 2000. Inhibition of fungal cell wall synthesizing enzymes by transcinnamaldehyde. Biosci. Biotechnol. Biochem. 64: 10611063.

Cakir, A., Kordali, S., Zengin, H., Izumi, S. and Hirata, T. 2004. Composition and antifungal activity of essential oils isolated from Hypericum hyssopifolium and Hypericum heterophyllum. Flavour Fragr. J. 19: 62-68.

Chandravadana, M. V., Nidiry, E. S. J., Khan, R. M. and Rao, M. S. 1993. Nematicidal activity of serpentine against Meloidogyne incognita. Fundam. Appl. Nematol. 17: 185-192.

Chang, H. T., Cheng, Y. H., Wu, C. L., Chang, S. T., Chang, T. T. and Su, Y. C. 2008. Antifungal activity of essential oil and its constituents from Calocedrus macrolepis var. formosana Florin leaf against plant pathogenic fungi. Bioresource Technol. 99: 6266-6270.

Chitwood, D. J. 2002. Phytochemical based strategies for nematode control. Annu. Rev. Phytopathol. 40: 221-249.

Cho, J.-Y., Choi, G. J., Lee, S.-W., Lim, H. K., Jang, K. S., Lim, C. H., Cho, K. Y. and Kim, J.-C. 2006a. In vivo antifungal activity against various plant pathogenic fungi of curcuminoids isolated from the rhizomes of Curcuma longa. Plant Pathology J. 22:
94-96.

Cho, J.-Y., Kim, H. Y., Choi, G. J., Jang, K. S., Lim, H. K., Lim, C. H., Cho, K. Y. and Kim, J.-C. 2006b. Dehydro-alphalapachone isolated from Catalpa ovata stems: activity against plant pathogenic fungi. Pest Manag. Sci. 62: 414-418.

Cho, J.-Y., Choi, G. J., Lee, S.-W., Jang, K. S., Kim, H. K., Kim, C. H., Cho, C. H., Lee, S. O., Cho, K. Y. and Kim, J.-C. 2006c. Antifungal activity against Colletotrichum spp. of curcuminoids isolated from Curcuma longa L. rhizomes. J. Microbiol. Biotechnol. 16: 280-285.

Cho, J.-Y., Choi, G. J., Son, S. W., Jang, K. S., Lim, H. K., Lee, S. O., Sung, N. D., Cho, K. Y. and Kim, J.-C. 2007. Isolation and antifungal activity of lignans from Myristica fragrans against various plant pathogenic fungi. Pest Manag. Sci. 63: 935-940.

Choi, G. J., Lee, S. W., Jang, K. S., Kim, J. S., Cho, K. Y. and Kim, J.-C. 2004. Effects of chrysophanol, parietin, and nepodin of Rumex crispus on barley and cucumber powdery mildews. Crop Prot. 23: 1215-1221.

Choi, I. H., Kim, J., Shin, S. C. and Park, I. K. 2007a. Nematicidal activity of monoterpenoids against the pine wood nematode Bursaphelenchus xylophilus. Russ. J. Nematol. 15: 35-40.

Choi, I. H., Park, J. Y., Shin, S. C., Kim, J. and Park, I. K. 2007 b. Nematicidal activity of medicinal plant essential oils against the pine wood nematode Bursaphelenchus xylophilus. Appl. Entomol. Zool. 42: 97-401.

Choi, N. H., Choi, G. J., Min, B. S., Jang, K. S., Choi, Y. H., Kang, M. S., Park, M. S., Choi, J. E., Bae, B. K. and Kim, J.-C. 2009. Effects of neolignans from the stem bark of Magnolia obovata on plant pathogenic fungi. J. Appl. Microbiol. 106: 20572063.

Choi, N. H., Kwon, H. R., Son, S. W., Choi, G. J., Choi, Y. H., Jang, K. S., Lee, S. O., Choi, J. E., Ngoc, L. H. and Kim, J.-C. 2008. Nematicidal activity of malabaricones isolated from Myristica malabarica fruit rinds against Bursaphelenchus xylophilus. Nematology 6: 801-807.

Copping, L. G. and Duke, S. O. 2007. Natural products that have been used commercially as crop protection agents. Pest Manag. Sci. 63: 524-554.

Copping, L. G. and Menn, J. J. 2000. Biopesticides: a review of their action, applications and efficacy. Pest Manag. Sci. 56: 651-676.

D’Addabbo, T., Carbonara, T., Leonetti, P., Radicci, V., Tava, A. and Avato, P. 2010. Control of plant parasitic nematodes with active saponins and biomass from Medicago sativa. Phytochem. Rev. DOI: 10.1007/s11101-010-9180-2.

Davis, E. L., Meyers, D. M., Dullum, C. J. and Feitelson, J. S. 1997. Nematicidal activity of fatty acid esters on soybean cyst and root nematodes. J. Nematol. 29: 677-684.

Dayan, F. E., Cantrell, C. L. and Duke, S. O. 2009. Natural products in crop protection. Bioorg. Med. Chem. 17: 40224034.

Echeverrigaray, S., Zacaria, J. and Beltrão, R. 2010. Nematicidal 
activity of monoterpenoids against the root-knot nematode Meloidogyne incognita. Phytopathology 100: 199-203.

Engelmeier, D. and Hadacek, F. 2006. Antifunal natural products: assays and applications. In: Advances in Phytomedicine, Naturally Occurring Bioactive Compounds, Vol. 3, ed. by Rai, M. and Carpenella, M. C., pp. 423-467. Elsevier Science B.V., Netherlands.

Ghisalberti, E. L. 2002. Secondary metabolites with antinematodal activity. In: Studies in Natural Products Chemistry, Vol. 26, ed. by Atta-ur-Rahman, pp. 425-506. Elsevier Science B.V., Netherlands.

Gonzalez-Coloma, A., Reina, M., Diaz, C. E. and Fraga, B. M. 2010. Natural product-based biopesticides for insect control. In: Comprehensive Natural Products II, ed. by L. Mander and H.-W. Liu, pp. 237-268. Elsevier Science B.V., Oxford, UK.

Gupta, R. and Sharma, N. K. 1993. A study of the nematicidal activity of allicin-an active principle in garlic, Allium sativum L., against root-knot nematode, Meloidogyne incognita (Kofoid and White, 1919) Chitwood, 1949. Int. J. Pest Manag. 39: 390-392.

Hong, L., Li, G., Zhou, W., Wang, X. and Zhang, K. 2007. Screening and isolation of a nematicidal sesquiterpene from Magnolia grandiflora L. Pest Manag. Sci. 63: 301-305.

Hu, K., Dong, A., Kobayashi, H., Iwasaki, S. and Yao, X. 2003. Antifungal agents from traditional chinese medicines against rice blast fungus Pyricularia oryzae Cavara. In: Plant-derived antimycotics: current trends and future prospects, ed. by M. Rai and D. Mares, pp. 525-549. The Haworth Press, Inc., Binghamton, NY, USA.

Isman, M. B. 2000a. Biopesticides based on phytochemicals. In: Koul, O. and Dhaliwal, G. S. (Eds.), Phytochemical Biopesticides. Harwood Academic, Amsterdam, Netherlands, pp. 1-12.

Isman, M. B. 2000b. Plant essential oils for pest and disease management. Crop Prot. 19: 603-608.

Isman, M. B. 2006. Botanical insecticides, deterrents and repellents in modern agriculture and an increasingly regulated world. Annu. Rev. Phytopathol. 51: 45-66.

Jeon, J.-H., Kim, Y.-K., Lee, S.-G., Lee, G.-H. and Lee, H.-S. 2011. Insecticidal activities of a Diospyros kaki root-isolated constituent and its derivatives against Nilaparvata lugens and Laodelphax striatellus. J. Asia Pacific Entomol. 14: 449-453.

Jespers, A. and De Waard, M. 1993. Natural products in plant protection. Neth. J. Plant. Pathol. 99: 109-117.

Kawazu, K., Nishii, Y. and Nakajima, S. 1980. Two nematicidal substances from roots of Cirsium japonicum. Agric. Biol. Chem. 44: 903-906.

Kim, M.-K., Choi, G. J. and Lee, H.-S. 2003. Fungicidal property of Curcuma longa L. rhizome-derived curcumin against phytopathogenic fungi in a greenhouse. J. Agric. Food Chem. 51: 1578-1581.

Kim, J.-C., Choi, G. J., Lee, S.-W., Kim, J.-S., Chung, K. Y. and Cho, K. Y. 2004a. Screening for antifungal extracts against various plant pathogenic fungi and control of powdery mildew with extracts of Achyranthes japonica and Rumex crispus. Pest Manag. Sci. 60: 803-808.

Kim, Y. M., Lee, C. H., Kim, H. G. and Lee, H. S. 2004 b. Anthraquinones isolated from Cassia tora (Leguminosae) seed show an antifungal property against phytopathogenic fungi. J. Agric. Food Chem. 52: 6096-6100.

Kim, J., Seo, S. M., Lee, S. G., Shin, S. C. and Park, I. K. 2008. Nematicidal activity of plant essential oils and components from coriander (Coriandrum sativum), oriental sweetgum (Liquidambar orientalis), and valerian (Valeriana wallichii) essential oils against pine wood nematode (Bursaphelenchus xylophilus). J. Agric. Food Chem. 56: 7316-7320.

Kong, J. O., Lee, S. M., Moon, Y. S., Lee, S. G. and Ahn, Y. J. 2006. Nematicidal activity of plant essential oils against Bursaphelenchus xylophilus (Nematoda: Aphelenchoididae). J. Asia-Pacific Entomol. 9: 173-178.

Kong, J. O., Lee, S. M., Moon, Y. S., Lee, S. G. and Ahn, Y. J. 2007a. Nematicidal activity of cassia and cinnamon oil compounds and related compounds toward Bursaphelenchus xylophilus (Nematoda: Parasitaphelenchidae). J. Nematol. 39: 31-36.

Kong, J. O., Park, I. K., Choi, K. S., Shin, S. C. and Ahn, Y. J. 2007b. Nematicidal and propagation activities of thyme red and white oil compounds toward Bursaphelenchus xylophilus (Nematoda: Parasitaphelenchidae). J. Nematol. 39: 237-242.

Lee, H. S. 2007. Fungicidal property of active component derived from Acorus gramineus rhizome against phytopathogenic fungi. Bioresource Technol. 98: 1324-1328.

Lee, H.-S., Shin, W.-K., Song, C., Cho, K.-Y. and Ahn, Y.-J. 2001. Insecticidal activities of ar-turmerone identified in Curcuma longa rhizome against Nilaparvata lugens (Homoptera: Delphacidae) and Plutella xylostella (Lepidoptera: Yponomeutidae). J. Asia Pacific Entomol. 4: 181-185.

Luo, D. Q., Wang, H., Tian, X., Shao, H. J. and Liu, J. K. 2005. Antifungal properties of pristimerin and celastrol isolated from Celastrus hypoleucus. Pest Manag. Sci. 61: 85-90.

Matsuda, K., Kimura, M., Komai, K. and Hamada, M. 1989. Nematicidal activities of (-)-N-methylcytisine and (-)anagyrine from Sophora flavescens against pine wood nematodes. Agric. Biol. Chem. 53: 2287-2288.

Matsuda, K., Yamada, K., Kimura, M. and Hamada, M. 1991. Nematicidal activity of matrine and its derivatives against pine wood nematodes. J. Agric. Food Chem. 39: 181-191.

Mordue, A. J. and Nisbet, A. J. 2000. Azadirachtin from the neem tree Azadirachta indica: its actions against insects. $A n$. Soc. Entomol. Bras. 29: 615-632.

Muller-Riebau, F., Berger, B. and Yegen, O. 1995. Chemical composition and fungitoxic properties to phytopathogenic fungi of essential oils of selected aromatic plants growing wild in Turkey. J. Agric. Food Chem. 43: 2262-2266.

Nidiry, E. S. J., Khan, R. M. and Reddy, P. P. 1993. In vitro 
nematicidal activity of Gloriosa superb seed extract against Meloidogyne incognita. Nematol. Medit. 21: 127-128.

Ntalli, N. G., Ferrari, F., Giannakou, I. and Menkissoglu-Spiroudi, U. 2011. Synergistic and antagonistic interactions of terpenes against Meloidogyne incognita and the nematicidal activity of essential oils from seven plants indigenous to Greece. Pest Manag. Sci. 67: 341-351.

Oerke, E. C. and Dehne, H.-W. 2004. Safeguarding productionlosses in major crops and the role of crop protection. Crop Prot. 23: 275-285.

Oka, Y., Nacar, S., Putievsky, E., Ravid, U., Yaniv, Z. and Spiegel, Y. 2000. Nematicidal activity of essential oils and their components against the root-knot nematode. Phytopathology 90: 710-715.

Park C., Kim S.-I. and Ahn Y.-J. 2003. Insecticidal activity of asarones identified in Acorus gramineus rhizome against three coleopteran stored-product insects. J. Stored Prod. Res. 39: 333-342.

Park, I. K., Kim, J., Lee, S. G. and Shin, S. C. 2007. Nematicidal activity of plant essential oils and components from ajowan (Trachyspermum ammi), allspice (Pimenta dioica) and litsea (Litsea cubeba) essential oils against pine wood nematode (Bursaphelenchus Xylophilus). J. Nematol. 39: 275-279.

Ping, G., Taiping, H., Rong, G., Qiu, C. and Shigui, L. 2001. Activity of the botanical aphicides 1,5-diphenyl-1-pentanone and 1,5-diphenyl-2-penten-1-one on two species of Aphididnae. Pest Manag. Sci. 57: 307-310.

Ploegn, A. T. 1999. Greenhouse studies on the effect of Marigolds (Tagetes spp.) on four Meloidogyne species. J. Nematol. 31: 62-69.

Rameshwar Singh, R. 2010. Mechanism of action of insecticidal secondary metabolites of plant origin. Crop Prot. 29: 13-920.

Saha, S., Walia, S., Kumar, J. and Parmar, B. S. 2010. Structurebiological activity relationships in triterpenic saponins: the relative activity of protobassic acid and its derivatives against plant pathogenic fungi. Pest Manag. Sci. 66: 825-831.

Sahni, S., Maurya, S., Singh, U. P., Singh, A. K., Singh, V. P. and Pandey, V. B. 2005. Antifungal activity of nor-securine against some phytopathogenic fungi. Mycobiology 33: 97-103.

Sánchez Deviala, S., Brodie, B. B., Rodriguez, E. and Gibson, D. M. 1998. The potential of thiarubrine $C$ as a nematicidal agent against plant-parasitic nematode. J. Nematol. 30: 192-200.
Saniewska, A., Jarecka, A., Bialy, Z. and Jurzysta, M. 2006. Antifungal activity of saponins originated from Medicago hybrida against some ornamental plant pathogens. Acta Agrobot. 59: 51-58.

Shakil, N. A., Pankaj Kumar, J., Pandey, R. K. and Saxena, D. B. 2008. Nematicidal prenylated flavanones from Phyllantus niruri. Phytochemistry 69: 759-764.

Singh, A. K., Pandey, M. B., Singh, S., Singh, A. K. and Singh, U. P. 2008. Antifungal activity of securinine against some plant pathogenic fungi. Mycobiology 36: 99-10.

Suga, T., Ohta, S., Munesada, K., Ide, N., Kurokawa, M., Shimizu, M. and Ohta, E. 1993. Endogenous pine wood nematicidal substances in pines, Pinus massoniana, P. strobus and P. palustris. Phytochemistry 33: 1395-1401.

Thoden, T. C., Boppré, M. and Hallmann, J. 2009a. Effects of pyrrolizidine alkaloids on the performance of plant-parasitic and free-living nematodes. Pest Manag. Sci. 65: 823-830.

Thoden, T. C., Hallmann, J. and Boppré, M. 2009b. Effects of plants containing pyrrolizidine alkaloids on the northern rootknot nematode Meloidogyne hapla. Europ. J. Plant Pathol. 123: $27-36$.

Udalova, Z. V., Zinov'eva, S. V., Vasil'eva, I. S. and Paseshnichenko, V. A. 2004. Correlation between the structure of plant steroids and their effects on phytoparasitic nematodes. Appl. Biochem. Microbiol. 40: 93-97.

Vidhyasekaran, P. 2004. Concise Encyclopedia of Plant Pathology. Food Products Press, New York, USA.

Yang, X., Yang, L., Wang, S., Yu, D. and Ni, H. 2007. Synergistic interaction of physcion and chrysophanol on plant powdery mildew. Pest Manag. Sci. 63: 511-515.

Yen, T. B., Chang, H. T., Hsieh, C. C. and Chang, S. T. 2008. Antifungal properties of ethanolic extract and its active compounds from Calocedrus macrolepis var. formosana (Florin) heartwood. Bioresource Technol. 99: 4871-4877.

Zhao, B. G. 1999. Nematicidal activity of quinolizidine alkaloids and the functional group pairs in their molecular structure. $J$. Chem. Ecol. 25: 2205-2214.

Zhou, C.-X., Liu, J.-Y., Ye, W.-C., Liu, C.-H. and Tan, R.-X. 2003. Neoverataline A and B, two antifungal alkaloids with a novel carbon skeleton from Veratrum taliense. Tetrahedron 59: 5743-5747. 